\author{
Prof. dr hab. Stanisław SWADŹBA \\ Uniwersytet Ekonomiczny w Katowicach \\ e-mail: stanislaw.swadzba@ue.katowice.pl \\ ORCID: 0000-0002-9006-3595
}

DOI: $10.15290 /$ oes.2019.01.95.02

\title{
SYSTEM GOSPODARCZY POLSKI W LATACH 1918-2018 ${ }^{1}$
}

\begin{abstract}
Streszczenie
Cel - Celem niniejszego artykułu jest przedstawienie ewolucji systemu gospodarczego Polski na przestrzeni ostatnich stu lat, od odzyskania niepodległości w 1918 r. do dnia dzisiejszego, a także próba uchwycenia jego specyficznych cech oraz pokazanie różnic systemowych między Polską a innymi krajami.

Metody - Wykorzystano różne metody badawcze, w tym: krytyczną analizę literatury przedmiotu, analizę historyczna, analizę porównawczą funkcjonujących systemów gospodarczych w Polsce w ostatnich stu latach, a także systemu gospodarczego Polski i innych krajów w tym okresie.

Opis badań - Przedmiotem rozważań jest system gospodarczy w skali makro (krajowy system gospodarczy). Ponadto system gospodarczy w wąskim znaczeniu, a więc sfera regulacyjna gospodarki. Ma on bezpośredni wpływ na wyniki gospodarcze kraju, a więc na sferę realna. W opracowaniu skupiono się na własności oraz mechanizmie koordynacji decyzji gospodarczych (ze szczególnym uwzględnieniem roli rynku i państwa), jako dwóch głównych wyznacznikach systemu gospodarczego.

Wyniki - Ostatnie sto lat Polski było również burzliwe pod względem zmian w systemie gospodarczym. Polska przeszła przez dwa megasystemy: kapitalizm i socjalizm. Od kapitalizmu do socjalizmu i z powrotem do kapitalizmu. W trakcie tych radykalnych zmian mieliśmy do czynienia z ewolucją systemu gospodarczego, zarówno w ramach systemu gospodarki rynkowej, jak i systemu gospodarki centralnie planowanej. Ponadto system gospodarczy Polski w poszczególnych podokresach posiadał specyficzne cechy i różnił się od systemu gospodarczego innych krajów funkcjonujących w tych dwóch megasystemach. Wynikało to ze specyficznych czynników społeczno-kulturowych Polski, a także określonej sytuacji historycznej, w jakiej znajdował się nasz kraj.
\end{abstract}

Słowa kluczowe: system gospodarczy Polski, analiza porównawcza systemów gospodarczych, okres międzywojenny, gospodarka centralnie planowana, transformacja systemowa

\section{POLAND'S ECONOMIC SYSTEM IN THE YEARS 1918-2018}

\section{Summary}

Purpose - The aim of this article is to present the evolution of Poland's economic system over the last hundred years, from regaining the independency in 1918 to the present day, and to try to capture its specific features and show the systemic differences between Poland and other countries.

1 Artykuł wpłyną 5 października 2018 r., zaakceptowano 13 grudnia $2018 \mathrm{r}$.

Article received 5 October 2018, accepted 13 December 2018. 
Research methods - Various research methods were used, including: critical analysis of the literature, historical analysis, comparative analysis of the economic systems in Poland in the last one hundred years, as well as the economic system of Poland and other countries during this period.

Description of research - The subject of consideration is the economic system in the macro scale (national economic system). In addition, we are interested in the economic system in the narrow sense - the regulatory sphere of the economy. It has a direct impact on the country's economic performance, and thus, on the real sphere. The study focuses on the ownership and the mechanism for coordinating economic decisions (with particular emphasis on the role of the market and the state) as the two main determinants of the economic system.

Finding - The last hundred years of Poland were also turbulent in terms of changes in the economic system. Poland has gone through two megasystems: capitalism and socialism. From capitalism to socialism and back to capitalism. During these radical changes we were dealing with the evolution of the economic system, both within the framework of the market economy system and the centrally planned economy system. In addition, the economic system of Poland in particular subperiods had specific features and differed from the economic system of other countries functioning in these two megasystems. This was due to the specific socio-cultural factors in Poland, as well as to the specific historical situation in which our country existed.

Key words: Poland's economic system, comparative economic studies, interwar period, centrally planned economy, systemic transformation

JEL classification: P51

\section{Wstęp}

System gospodarczy - w zależności od konkretnych zainteresowań badaczy - jest różnorodnie definiowany. W podręcznikach ekonomii można się spotkać z jego różnymi interpretacjami. Nie wnikając w szczegóły można, za T. Kowalikiem, lapidarnie powiedzieć, że jest to gospodarka teoretycznie opisana [Kowalik, 2000, s. 12]. Poszczególne gospodarki różnią się między sobą. Takich opisów będzie wiele. Nic więc dziwnego, że analiza porównawcza systemów gospodarczych (comparative economic studies) - pomimo upadku systemu socjalistycznego i dominacji kapitalistycznej gospodarki rynkowej - cieszy się ciagłym powodzeniem. Nie ma bowiem jednego rynku, jednej gospodarki rynkowej. W praktyce mamy do czynienia z różnymi jej modelami. Porównywać więc możemy realnie istniejące systemy gospodarcze różnych krajów w przestrzeni, a także zmiany systemowe (rewolucyjne bądź ewolucyjne) wewnątrz danego kraju w czasie.

Przedmiotem rozważań zawartych w artykule będzie system gospodarczy w skali makro (krajowy system gospodarczy). Ponadto w kregu zainteresowania znalazł się system gospodarczy $\mathrm{w}$ wąskim znaczeniu, a więc sfera regulacyjna gospodarki (inaczej mówiąc będzie to system funkcjonowania gospodarki, mechanizm gospodarczy, czy porządek gospodarczy) [Balcerowicz, 1993, s. 15]. Ma ona bezpośredni wpływ na wyniki gospodarcze kraju, a więc na sferę realną. W opracowaniu skupiono się na własności oraz mechanizmie koordynacji decyzji gospodarczych (ze 
szczególnym uwzględnieniem roli rynku i państwa) jako dwóch głównych wyznacznikach systemu gospodarczego ${ }^{2}$.

Celem niniejszego artykułu jest pokazanie zmian w systemie gospodarczym Polski na przestrzeni ostatnich stu lat, od odzyskania niepodległości w 1918 r. do dnia dzisiejszego. Ponadto jest nim próba uchwycenia jego specyficznych cech, społeczno-politycznych uwarunkowań, jego ewolucji w poszczególnych podokresach, a także - w pewnym stopniu - pokazanie różnic systemowych między Polską a innymi krajami.

Temu celowi podporządkowany został układ opracowania, które składa się z czterech części. Podział ten ma charakter historyczny. W pierwszej pokazano specyfikę systemu gospodarczego Polski okresu międzywojennego. Druga poświęcona została powojennemu systemowi gospodarki centralnie planowanej. W części trzeciej zajęto się okresem transformacji systemowej i ugruntowaniem gospodarki rynkowej w Polsce. W specjalnie wyodrębnionej części czwartej zajęto się ostatnimi latami, a mianowicie okresem modyfikacji systemowej (budowa IV RP) oraz perspektywami systemu gospodarczego Polski. W zakończeniu zawarto wnioski z przeprowadzonych rozważań.

W artykule wykorzystano różne metody badawcze, w tym: krytyczną analizę literatury przedmiotu, analizę historyczną, analizę porównawczą funkcjonujących systemów gospodarczych w Polsce w ostatnich stu latach, a także systemu gospodarczego Polski i innych krajów w tym okresie.

\section{Specyfika systemu gospodarczego Polski okresu międzywojennego}

Na system gospodarczy Polski okresu międzywojennego wpływ miały zarówno czynniki zewnętrzne, jak i wewnętrzne. Jeżeli chodzi o czynniki zewnętrzne to były to procesy społeczno-gospodarcze zachodzace w gospodarce światowej na przełomie XIX i XX wieku, a mianowicie: przechodzenie od wolnej konkurencji do monopolizacji (powstawanie karteli i koncernów), powstanie kapitału finansowego, eksport kapitału, rozwój kapitalizmu i imperializmu, nawrót do protekcjonizmu, upowszechnienie systemu waluty złotej [Szpak, 2003, s. 191-199]. Zmiany w kapitalizmie w tym okresie sprawiły, że miał on inny charakter w porównaniu z okresem do 1870 r. Nie mogły one pozostać bez wpływu na kształtowanie się kapitalizmu w odrodzonej Polsce. Jednak z pewnością większy wpływ wywarły czynniki wewnętrzne. Po pierwsze, było to ogromne zróżnicowanie obszarów ziem Polski pod poszczególnymi zaborami. Odnosiło się to nie tylko do sfery realnej (poziom rozwoju gospodarczego), ale i regulacyjnej. Były to odmienne systemy, funkcjonował tam inny kapitalizm. Jeżeli różnice te były mniejsze między zaborem pruskim

2 Takie podejście reprezentuje większość autorów zajmujących się problematyką systemów gospodarczych [m.in.: Balcerowicz, 1993; Bałtowski, 2009; Kozłowski, 2004; Swadźba, 2009]. 
i austriackim, to w zaborze rosyjskim jeszcze w dużym stopniu funkcjonowała gospodarka naturalna. To były dopiero początki kapitalistycznej gospodarki rynkowej. Po drugie, były to ogromne zniszczenia wojenne w wyniku kilkukrotnego przesuwania się linii frontu na niektórych obszarach Polski. W efekcie, poziom rozwoju społeczno-gospodarczego rodzącej się Polski był niższy w porównaniu z krajami Europy Zachodniej. Stąd system gospodarczy miał cechy kapitalizmu peryferyjnego i różnił się od systemu gospodarczego Wielkiej Brytanii, Francji, czy Niemiec.

Kształtowanie się systemu gospodarczego Polski w tym okresie było procesem powolnym, tak jak stopniowo kształtowała się Polska. Data 11 listopada 1918 r. ma symboliczny charakter. Nieznane były jeszcze granice Polski ze wszystkimi jej sąsiadami. Dopiero w 1921 r. po wojnie polsko-bolszewickiej ustalono granice z Rosja radziecka, a w 1922 r. przyłączono Śląsk do Polski. Tak więc, lata 1918-1923 to okres gospodarki wojennej. W pierwszym okresie niepodległej Polski był to więc specyficzny system gospodarczy. Charakterystyczny dla tego okresu etatyzm, wprowadzony jeszcze przez zaborców w okresie wojny, pozostał, a próby odejścia były niekonsekwentne [Landau, Tomaszewski, 1967, t. I, s. 77]. System gospodarczy Polski kształtował się więc powoli. Inny był w pierwszych latach niepodległości, a inny u schyłku okresu międzywojennego.

Jednym z głównych czynników charakteryzujących system gospodarczy to własność. Podstawowa jej formą w okresie międzywojennym była własność prywatna, chociaż gwarantowana była wszelka forma własności. W artykule 99 konstytucji marcowej z 1921 r. znalazło się stwierdzenie: „Rzeczpospolita Polska uznaje wszelką własność (...) jako jedną z najważniejszych podstaw ustroju społecznego i prawnego oraz poręcza wszystkim obywatelom, instytucjom i społecznościom ochronę ich mienia, a dopuszcza tylko w wypadkach, ustawa przewidzianych, zniesienie lub ograniczenie własności, czy to osobistej, czy to zbiorowej, ze względów wyższej użyteczności, za odszkodowaniem" [Landau, Roszkowski, 1995, s. 178].

$\mathrm{Na}$ wsi dużą rolę odgrywała wielka własność ziemi. Według danych spisu z 1921 r. 0,8\% ogółu gospodarstw o powierzchni przekraczającej 100 ha dysponowało 44,8\% powierzchni ziemi [Mieszczankowski, 1960, s. 19]. Reforma rolna z 1925 r. tylko w niewielkim stopniu przyczyniła się do zmiany struktury własności. Objęła jedynie 7\% (2654 tys. ha) ogółu użytków rolnych w Polsce. W latach 19191939 rozparcelowano w Polsce około 2655 tys. ha ziemi, z czego 1864 tys. ha należało do właścicieli prywatnych. Nie byli z niej zadowoleni zarówno ziemianie, jak i chłopi. Reforma rolna nie była tak radykalna jak w Rumunii, czy krajach bałtyckich. Generalnie należy ją ocenić pozytywnie [Landau, Roszkowski, 1995, s. 38, 179, 184]. Należy dodać, że reforma rolna nie kolidowała $z$ istotą systemu kapitalistycznego.

Wysoki był odsetek własności zagranicznej. Generalnie polski kapitał po I wojnie światowej był słaby. Stąd polityka państwa nastawiona była na ściaganie kapitału zagranicznego. Jednak kapitał ten nie tworzył tzw. green field investments. Było to wykupywanie akcji przedsiębiorstw już istniejących. W 1927 r. kapitał zagraniczny stanowił 21,1\%, a w 1934 r. 47,1\% kapitałów własnych polskich spółek akcyjnych. Sytuacja zmieniła się po kryzysie kiedy to - bardziej z przyczyn politycznych - rząd 
zdecydował się na wykupienie kilku przedsiębiorstw niemieckich. W efekcie udział kapitału zagranicznego w 1938 r. zmniejszył się do 42,9\% [Landau, Tomaszewski, 1967, t. II, s. 78, t. IV, s. 145].

Własność państwowa w Polsce - w porównaniu z innymi krajami - była średnio rozwinięta. W 1936 r. obejmowała, poza majątkami rolnymi, lasami, kolejami, kopalnie soli kamiennej i potasowej, rafinerie w Drohobyczu, fabrykę nawozów azotowych w Chorzowie, cztery zakłady zbrojeniowe i kilka mniejszych przedsiębiorstw. Lista ta znacznie zwiększyła się po Wielkim Kryzysie w efekcie czego udział państwa w niektórych gałęziach przemysłu był bardzo wysoki (sól potasowa, samochody, samoloty $-100 \%$, gaz ziemny $-84 \%$, produkcja hutnicza $-55 \%$, chemiczna - 25\%, wydobycie węgla - 19\%) [Landau, Roszkowski, 1995, s. 208, 211].

Jeżeli chodzi o rolę rynku i państwa (drugi ważny czynnik charakteryzujący system gospodarczy) to - jak już wspomniano - początkowo był silny etatyzm (konsekwencja wojny). Silny był sektor państwowy (brak kapitału krajowego i słaby napływ zagranicznego). Rola państwa była bardzo duża (system gospodarki wojennej). Jednak trudno było odejść od niego. Mimo krytyki etatyzm rósł. Po kryzysie rozwijał się nadal, mimo że rząd starał się ograniczyć zasięg gospodarki państwowej [Landau, Roszkowski, 1995, s. 54]. „Druga Rzeczpospolita zdana więc była na rozwój gospodarki państwowej, mimo że wcale tego nie chciała i próbowała się bronić przed tym procesem" [Landau, Roszkowski, 1995, s. 56]. Jednak etatyzm to tylko część polityki gospodarczej państwa. Mieliśmy również do czynienia z okresem leseferyzmu, wiara w wolna gospodarkę rynkową (okres przed Wielkim Kryzysem), a także latami w których dominowało pośrednie oddziaływanie państwa na gospodarkę (okres dominacji nowego interwencjonizmu państwowego po Wielkim Kryzysie) [Landau, Roszkowski, 1995, s. 56-74].

Zróżnicowana była w tym okresie polityka gospodarcza państwa. Początkowo wspierano rolnictwo, później (po kryzysie) przemysł. Dowodem na to może być czteroletni plan inwestycyjny (1936-1940) E. Kwiatkowskiego w ramach którego rząd zainicjował budowę Centralnego Okręgu Przemysłowego. Zmieniała się również strategia dotycząca wspierania rynku wewnętrznego bądź zagranicznego. Nie można mówić o jednolitej polityce w tym zakresie [Landau, Roszkowski, 1995, s. 11-32].

Reasumując, należy stwierdzić, że po uzyskaniu niepodległości w Polsce ukształtował się system kapitalistyczny. Taki system - mniej lub bardziej rozwinięty funkcjonował wcześniej w państwach zaborczych. System ten kształtował się powoli, tak jak stopniowo konsolidowało się nowe państwo. System ten - chociaż funkcjonował niewiele ponad 20 lat - przyjmował różne oblicza. Decydowały o tym czynniki wewnętrzne (sytuacja społeczno-polityczna i poziom rozwoju gospodarczego), jak i zewnętrzne (wpływ chociażby kryzysu gospodarczego na zmiany systemowe w gospodarce). Niewątpliwie był to system kapitalistyczny w którym dużą rolę odgrywało państwo. Był to kapitalizm peryferyjny. 


\section{System gospodarki centralnie planowanej po II wojnie światowej}

W wyniku drugiej wojny światowej w Polsce - po jej zakończeniu - ukształtował się zupełnie nowy system gospodarczy. Trzeba jednak dodać, że pierwsze lata nie zapowiadały tego. PPR odcinała się od stwierdzenia, że chce wprowadzić radziecki model gospodarczy. W Manifeście PKWN nie było mowy o nacjonalizacji przemysłu, lecz o potrzebie wspierania inicjatywy prywatnej oraz reformie rolnej, która była powszechnie popierana (reformę z okresu międzywojennego uznawano za niewystarczająca). Manifest PKWN okazał się jednak materiałem propagandowodezinformacyjnym i wprowadzał społeczeństwo w błąd [Landau, Roszkowski, 1995, s. 88-89, 226-231].

Szybko unaoczniło się, że Polska nie poszła w stronę modelu socjaldemokratycznego, jak się początkowo wydawało. W latach 1947-1948 rozpoczął się szybki marsz w stronę systemu socjalistycznego. Rozpoczęły się radykalne zmiany systemu gospodarczego w sferze własności i regulacji [Bałtowski, 2009, s. 142-164]. Początek lat pięćdziesiątych XX wieku to próba wprowadzenia modelu radzieckiego z silną industrializacją kraju, a ponadto dalszą nacjonalizacją wykraczająca poza wcześniejszą ustawę nacjonalizacyjną (objęła również rzemiosło i handel) oraz kolektywizacją na wsi3.

II połowa lat pięćdziesiątych to krótkotrwała odwilż. Rozpoczęło się odchodzenie od modelu radzieckiego, jednak nie podważano istoty systemu socjalistycznego. Wprowadzono nieco demokracji (pojawienie się organów przedstawicielskich załóg pracowniczych w przedsiębiorstwie) i decentralizacji (zmiana sposobu podejmowanie decyzji w przedsiębiorstwie). Jednak był to krótki okres, w latach sześćdziesiątych i siedemdziesiątych XX wieku nastapił czas stabilizacji systemu. Można było sądzić, że tak już pozostanie.

Większe zmiany w systemie gospodarczym Polski zachodzą w latach osiemdziesiątych XX wieku. Początkowo były one wymuszone przez „Solidarność”, a z czasem (po stanie wojennym) była to odgórna próba reformy systemu. Zaszły zmiany zarówno w systemie własności (np. pojawienie się kapitału zagranicznego), jak i w systemie regulacji (słynne „3×S”, zmiany w planowaniu, funkcjonowaniu systemu bankowego, pewna liberalizacja w ustalaniu cen itp.). Należy jednak dodać, że była to jedynie próba utrzymania istniejącego systemu. To nie były działania majace na celu przygotowanie kraju do wprowadzenia nowego systemu.

Reasumując, należy stwierdzić, że socjalizm (gospodarka centralnie planowana) nie był jednolitym systemem gospodarczym. Tak jak nie ma jednego kapitalizmu (gospodarki rynkowej), tak samo nie było jednolitości w przypadku tego systemu. W różnych krajach funkcjonowały różne jego odmiany. Ale także zmieniał się on wewnątrz danego kraju. Tak było również w Polsce. Chociaż system ten trwał

3 Dalsze rozważania na temat systemu gospodarki centralnie planowanej w Polsce chociażby ze względu na ograniczona objętość artykułu - będą bardzo skrótowe. Obszerna jest literatura na ten temat. Na szczególne podkreślenie zasługuje publikacja M. Bałtowskiego [2009]. 
jedynie 45 lat, to przechodził przez różne etapy (modele socjalizmu). Raz był to socjalizm z bardziej, a innym razem z mniej „ludzką twarzą". Jednak cały ten okres posiadał dwie cechy konstytutywne dla gospodarki socjalistycznej: własność uspołeczniona, regulacja - scentralizowana.

\section{Transformacja systemowa: od gospodarki centralnie planowanej do gospodarki rynkowej}

Upadek systemu realnego socjalizmu rozpoczął okres transformacji systemowej, proces całkowitego i kompleksowego przeobrażenia systemu, przebudowy jednego systemu na inny, czy - tak też można powiedzieć - uformowania i zorganizowania systemu od nowa. Powyższa transformacja jest rozumiana jako przejście od gospodarki centralnie planowanej typu socjalistycznego do gospodarki rynkowej typu kapitalistycznego. To przejście od jednego do drugiego systemu oznaczało zastapienie planu centralnego mechanizmem rynkowym oraz demokratyczne przemiany ustrojowe. Bardzo skrótowo można powiedzieć: Transformacja $=$ Rynek + Demokratyzacja ${ }^{4}$.

Taka transformacja rozpoczęła się we wszystkich krajach Europy ŚrodkowoWschodniej, w tym również w Polsce ${ }^{5}$. Nie ma zgodności co do jej początku. Niektórzy mówią, że jest to data pierwszych częściowo wolnych czerwcowych wyborów lub data wyboru T. Mazowieckiego na pierwszego niekomunistycznego premiera po II wojnie światowej. Dla większości jest to jednak początek realizacji Planu Balcerowicza, a więc 1 stycznia 1990 r. Od tego dnia zaczęły obowiązywać pierwsze ustawy, które radykalnie zmieniły system gospodarczy Polski' ${ }^{6}$.

W tym miejscu należałoby się również odnieść do daty (z pewnością symbolicznej) końca transformacji. W tej kwestii różnice poglądów są jeszcze większe. Dla niektórych transformacja systemowa ciagle trwa. Dla Autora - tak jak z pewnością dla większości osób zajmujących się tą problematyką - Polska osiągnęła już stadium

4 Na temat transformacji systemowej pisali m.in. (w ujęciu alfabetycznym): L. Balcerowicz, M. Bałtowski i M. Miszewski, J. Beksiak, H. Chołaj, B. Fiedor, Z. Hockuba, G. Kołodko, D. Rosati, W. Trzeciakowski, W. Wilczyński, J. Wilkin, A. Wojtyna, M.G. Woźniak i wielu innych. Ze względu na objętość artykułu ich publikacje nie będą cytowane [Swadźba, 2007].

5 Niektórzy podkreślaja, że jest to w zasadzie powrót do kapitalizmu (restytucja lub restauracja kapitalizmu), bo taki system już wcześniej istniał w Polsce (m. in. wymienieni powyżej J. Beksiak, H. Chołaj i J. Wilkin), czy - podkreślając znaczenie reform w ostatnim okresie gospodarki socjalistycznej - przejście od renowacji socjalizmu do restauracji kapitalizmu [Kołodko, 1999, s. 46].

6 Te zagadnienia $\mathrm{i}$ inne zagadnienia związane $\mathrm{z}$ transformacją są powszechnie znane, tak więc - również ze względu na ograniczoną objętość artykułu - nie będą przedmiotem analizy. Ograniczono się do tych aspektów, które będą przydatne do rozważań zawartych w ostatniej części artykułu. 
demokratycznej gospodarki rynkowej, a cezura czasową mogłaby być data przystapienia Polski do UE, a więc 1 maja 2004 r. UE wyznacza bowiem warunki, jakie kraje kandydackie muszą spełnić. Wśród nich jest gospodarka rynkowa i system demokratyczny. Przystapienie do UE oznaczało spełnienie tych warunków, które były równocześnie celem transformacji. Można więc mówić o jej zakończeniu, chociaż wiele zadań nie zostało do tego momentu, a nawet do dnia dzisiejszego, zrealizowanych. Zmiany o charakterze systemowym ciagle są realizowane, ale nie możemy ich już nazywać transformacją systemowa. To już jest modyfikacja nowego systemu gospodarki rynkowej, czy jego reformowanie.

Powyższą transformację, pomimo wystąienia wielu jej negatywnych skutków (zwłaszcza w pierwszym okresie), należy ocenić pozytywnie. Polska - przez wiele organizacji międzynarodowych i rządy państw wysoko rozwiniętych - została uznana za prymusa Europy i traktowana była jako wzór w przechodzeniu od gospodarki centralnie planowanej do gospodarki rynkowej. Pozytywna ocena odnosiła się zarówno do sfery realnej (poprawa wskaźników makroekonomicznych, zwłaszcza wysokie tempo wzrostu gospodarczego oraz wzrost PKB per capita), jak i sfery regulacji (funkcjonowanie gospodarki rynkowej).

Mówiąc o transformacji systemowej nie można pominąc kwestii wyboru docelowego modelu gospodarczego. Nie ma bowiem jednego kapitalizmu, jednej gospodarki rynkowej. Polska na początku lat dziewięćdziesiątych XX wieku stanęła przed możliwością budowy własnego, nie narzuconego z zewnątrz systemu gospodarczego. Akceptacja transformacji systemowej nie oznaczała zgodności co do tego, w jakim kierunku powinna pójść Polska. Wśród rozważań polskich ekonomistów wyróżnić można było kilka grup poglądów na ten temat? ${ }^{7}$ Jednak dyskusja szybko ucichła. Kiedy wejście Polski do UE stało się coraz bardziej realne i konieczne było dostosowanie się do wymogów unijnych, dyskusja na ten temat stała się bezzasadna. Jasne stało się, że tym modelem będzie kształtujący się coraz bardziej - wraz z postępującym procesem pogłębiania integracji gospodarczej - europejski (unijny) model kapitalizmu 8 .

Specyficzną cechą polskiej transformacji systemowej był wiec jej dualizm. Była to transformacja do gospodarki rynkowej w ogóle oraz transformacja do wymogów konkretnej gospodarki - gospodarki UE. Tej cechy nie posiadały kraje transformujące się, które nie aspirowały do członkostwa w UE. Tak więc polską transformację systemową napędzała powszechna chęć przystąpienia do struktur unijnych, co osta-

7 Była to grupa liberałów, konstruktywistów, zwolenników kontekstu kulturowego, społecznej gospodarki rynkowej, modelu szwedzkiego oraz tzw. trzeciej drogi [Swadźba, 2007].

8 To nowy model gospodarki rynkowej (kapitalizmu), na który zwraca uwagę coraz więcej autorów. Model, który zawiera elementy wcześniej znanych modeli (anglosaski, społecznej gospodarki rynkowej, czy model szwedzki). Można mówić o zacieraniu się różnic między nimi (konwergencji systemowej) i wyłanianiu się nowego modelu. Przykładem tego może być Wielka Brytania i Szwecja, gdzie miało miejsce odejście od skrajnych elementów charakterystycznych dla odmiennych modeli gospodarczych tych państw. 
tecznie potwierdziły wyniki referendum, w którym prawie 3/4 społeczeństwa głosowało za członkostwem Polski w UE. Wola członkostwa w UE nadała więc w dużym stopniu kształt nowemu systemowi gospodarczemu Polski, który ukształtował się na przełomie XX i XXI wieku. Suweren dokonał wyboru systemu gospodarczego, w jakim zaczęła funkcjonować Polska - była nim kapitalistyczna i demokratyczna (w rozumieniu Unii Europejskiej) gospodarka rynkowa.

Czy powyższy model kapitalistycznej gospodarki rynkowej ukształtowany w ostatniej dekadzie XX i pierwszej dekadzie XXI wieku jest wciąż aktualny? Wydarzenia ostatnich lat pokazuja, że można mieć co do tego coraz większe wattpliwości.

\section{Modyfikacja systemowa ostatnich lat. W jakim kierunku zmierza Polska?}

Przejęcie władzy przez PIS w 2015 r. spowodowało wprowadzenie wielu zmian w polityce i gospodarce. Zanegowane zostały osiagnięcia okresu transformacji. W sferze realnej odzwierciedlało to hasło „Polska w ruinie”. Również przyjęte w tym okresie rozwiązania systemowe uznano za niewłaściwe. Zainicjowane reformy objęły więc także sferę regulacyjna. Rozpoczęła się „Dobra zmiana” (to hasło z kolei odzwierciedla konieczność zmian w sferze regulacji). Celem stał się nowy system społeczno-gospodarczy - IV RP.

W krótkim okresie dokonano wielu zmian, głównie w zakresie sądownictwa (Trybunał Konstytucyjny, Sąd Najwyższy, Krajowa Rada Sądownictwa). Niektóre z nich uznane zostały za niekonstytucyjne i spotkały się z ostrą krytyką wielu organizacji międzynarodowych, w tym instytucji unijnych. Stąd podjęte zostały działania „dyscyplinujące” polski rząd za naruszenie Art. 2 Traktatu o UE. Zgodnie z Art. 7 grożą nam sankcje za naruszenie przez państwo członkowskie wartości Unii. Krytyka podjętych reform przez UE potraktowana została jako dyktat władz unijnych, na który suwerenny rząd Polski nie może sobie pozwolić. Zdaniem rządu, nie będzie nam Unia narzucać, co mamy robić. $\mathrm{Na}$ atak UE odpowiedzią był kontratak PIS-u.

Chociaż powyższe zmiany odnoszą się bezpośrednio do systemu politycznego, to mają one również wpływ na system gospodarczy. Te systemy są ze sobą ściśle powiązane. Wraz z systemem kulturowym tworzą system społeczno-gospodarczy. Z tego względu należałoby się zastanowić nad specyfiką obecnego systemu gospodarczego Polski oraz kierunku w jakim on ewoluuje.

Jeżeli celem transformacji systemowej było przejście do gospodarki rynkowej, to należy przypomnieć, że był to określony typ tej gospodarki, a mianowicie model unijny. Czy wobec ostatnich zmian nie należy uznać, że docelowym modelem nie jest już model unijny? Z pewnością mamy do czynienia z odchodzeniem od tego modelu gospodarczego. Jeżeli gospodarka Polski pozostaje nadal gospodarka rynkowa, to $z$ pewnościa coraz bardziej odbiega od gospodarki demokratycznej w rozumieniu UE, a co jest - o czym należy przypomnieć - warunkiem członkostwa. Przy obecnym stanie polskiej demokracji nie wstapilibyśmy do UE. 
To, że Polska staje się coraz mniej demokratycznym krajem pokazuje indeks demokracji opracowywany od 2006 r. przez The Economist Inteligency Unit. Polska najwyższy poziom osiagnęła w 2014 r. - 7,47 (w skali 1-10). Od 2015 r. wartość indeksu rokrocznie spada i w 2017 r. wyniosła 6,67 (53. miejsce na 167 krajów). Polska znajduje się w przedziale „wadliwych demokracij” (6-8 punktów). Najniższy wynik Polska osiagnęła w subindeksie „Funkcjonowanie rządu” $(4,38)$, a więc mieści się już w przedziale „systemy hybrydowe” (4-6 punktów) [Democracy Index, 2017].

Z pewnością polskiemu rządowi Unia jest bliska, ale prowadząca politykę zgodnie jego oczekiwaniami. Polska nie jest jednak w stanie zreformować UE, narzucić jej preferowanych przez siebie rozwiązań. Nie ma szans na pozyskanie niezbędnej większości do przeprowadzenia zmian. Liczba sojuszników Polski w UE systematycznie maleje. Nie wchodzi więc w grę model unijny w wersji polskiej. Tak więc, jeżeli nie model unijny, to co nas czeka? $\mathrm{Z}$ punktu widzenia koegzystencji rynku i demokracji bliższy rządowi jest z pewnością system gospodarczy Turcji, czy Rosji. $\mathrm{Z}$ kolei $\mathrm{z}$ punktu widzenia wzrostu znaczenia roli państwa $\mathrm{w}$ gospodarce (zwiększenie jej aktywności, proponowane nowe rządowe projekty inwestycyjne, renacjonalizacja, nacjonalizm gospodarczy itp.) to model latynoamerykański z lat osiemdziesiątych i dziewięćdziesiątych XX wieku. Jednak pójście w tym kierunku, wprowadzenie takich rozwiązań systemowych, byłoby równoznaczne z „Polexitem”.

Tak więc, ostatnie lata to odchodzenie od dotychczasowego systemu gospodarczego. Oczywiście nie od fundamentalnych zasad gospodarki rynkowej. Zachodzą jednak zmiany w systemie własności i oddziaływania na gospodarkę, a więc dwóch głównych czynnikach określających charakter systemu gospodarczego. To wszystko ciagle mieści się w ramach stwierdzenia: „Nie ma jednego rynku, nie ma jednej gospodarki rynkowej”. Można powiedzieć, że odchodząc częściowo od systemu gospodarczego, ukształtowanego w wyniku transformacji, w pewnym stopniu wracamy do tego, co było wcześniej. Z II RP jest to etatyzm. Przykładem tego mogą być planowane duże inwestycje państwowe typu centralny port lotniczy (porównywalny z budową Gdyni), produkcja samochodów elektrycznych, promów, budowa kanału Wisła - Odra itp. Z okresu PRL jest to silne upolitycznienie gospodarki, podejmowanie decyzji na szczeblu partyjnym (w myśl zasady „rząd rządzi, partia kieruje”), koncepcja narodowych championów, ręczne sterownie spółkami skarbu państwa, próby podporządkowania sobie przedsiębiorstw prywatnych, a także przygotowywane $z$ rozmachem wspomniane wcześniej plany inwestycyjne. Trzeba powiedzieć, że większość z nich nie ma uzasadnienia ekonomicznego i nie pasuje do dzisiejszych czasów.

Z tego powodu możemy mówić o zagrożeniach dla Polski. Zwracają na to uwagę reprezentujący odmienne opcje polityczne główni praktycy i teoretycy naszej transformacji systemowej. Według G.W. Kołodki są to: nowy nacjonalizm gospodarczy (coś co w ostatnich latach zagraża światu, ale również Polsce), kapitalizm państwowy, neosocjalistyczny eksperyment, polonocentryzm, czy „narcyzm” rządowy [Kołodko, Koźmiński, 2017]. W jeszcze większym stopniu obecną sytuację krytykuje L. Balcerowicz, który pisze, że Polska zmierza w kierunku kapitalizmu upolitycznionego („,crony capitalism”). PIS cofa nasz ustrój we wszystkich głównych 
dziedzinach, przede wszystkim państwa prawa. Atak na Trybunał Konstytucyjny, bez względu na jego wady, to atak na państwo prawa, a jego przeciwieństwem jest państwo policyjne. PIS głosi hasła antykomunistyczne, a jest najbardziej postkomunistyczna partia pod względem kierunku zmian ustrojowych [Balcerowicz, 2016, s. 29-20]. Polska uzyskała już dawno status demokracji skonsolidowanej. Zdaniem A. Przeworskiego takie demokracje rzadko upadaja. Tam gdzie się to wydarzyło występowały inne warunki. Polsce to nie powinno się przydarzyć. Czy jednak możemy być tego pewni? W ostatnich latach politycy nauczyli się niszczyć demokrację, udając, że nic złego nie robią [Możemy lepiej!, 2018]. Można przychylić się do stwierdzenia, że to co się dzieje jest próbą realizacji retrotopii (nostalgia za przeszłościa). Z. Bauman tym pojęciem nazwał próbę rekonstrukcji modeli społecznogospodarczych z przełomu XIX i XX wieku [Bauman, 2018]. Czy w tym kierunku pójdzie Polska?

Jeżeli chodzi o perspektywy, w jakim kierunku pójdzie system gospodarczy Polski, to jeszcze nie tak dawno sprawa była jasna. Będzie to zależeć od tego, w jakim kierunku pójdzie UE. Przyspieszy, czy zwolni tempo integracji [Swadźba, 2007]. Będziemy płynąć wraz z głównym nurtem integracji europejskiej. Tak jednak już nie jest. Co prawda, w ostatnich latach zmieniła się również UE, ale przede wszystkim zmieniła się Polska. Nowy kierunek, w jakim mamy podążać, tym razem wybraliśmy sami. Nie jest on jeszcze ściśle określony i pewny. Istnieje szansa powrotu na wcześniejsze tory - gospodarki rynkowej i demokratycznej w rozumieniu UE. Okazuje się, że wciąż aktualne są pytania: Jaki kapitalizm? Jaka Polska? [Wilkin, 1995].

\section{Podsumowanie}

Przeprowadzone rozważania nad systemem gospodarczym Polski w latach 19182018 pozwalają na sformułowanie następujących wniosków:

- Ostatnie sto lat w historii Polski było bardzo burzliwe, również pod względem zmian w systemie gospodarczym. Polska przeszła przez dwa megasystemy: kapitalizm i socjalizm. Od kapitalizmu do socjalizmu i z powrotem do kapitalizmu.

- W trakcie tych radykalnych zmian mieliśmy do czynienia z ewolucją systemu gospodarczego, zarówno w ramach systemu gospodarki rynkowej, jak i systemu gospodarki centralnie planowanej. Zmiany te często również były bardzo gwałtowne.

- W odróżnieniu od Polski, wiele państw świata nie odnotowało w tym czasie większych zmian. Występował tam system demokratycznej gospodarki rynkowej, którego główne cechy pozostały niezmienione.

- System gospodarczy Polski w poszczególnych podokresach posiadał specyficzne cechy i różnił się od systemu gospodarczego innych krajów funkcjonujących w tych dwóch megasystemach. Wynikało to ze specyficznych czynników społeczno-kulturowych Polski, a także określonej sytuacji historycznej, w jakiej znajdował się nasz kraj. 
- Przechodząc od jednego do drugiego systemu zmieniały się jego podstawowe zasady. Mieliśmy i mamy do czynienia często z bezwzględnym odrzucaniem tego, co było wcześniej. Nie zawsze to było właściwe. Z drugiej strony, istniały $\mathrm{i}$ istnieją elementy starego systemu (jego pozostałości) w nowym systemie, które $-z$ różnych przyczyn - nie zostały usunięte. Ponadto następuje też powrót do niektórych wyznaczników minionego systemu, co również jest bardzo dyskusyjne.

- System gospodarczy (sfera regulacji) powinien mieć przełożenie na poziom dobrobytu społeczeństwa (sfera realna). W przeszłości w Polsce z tym różnie bywało. Ostatnie lata przyniosły znaczną poprawę życia naszego społeczeństwa. Bez watpienia jest to efekt przeprowadzonej transformacji systemowej - przejścia do gospodarki rynkowej i demokratycznej, silnie zintegrowanej z UE. Tylko taki system przyczyni się do osiagnięcia tego celu. Polska powinna pozostać w UE. System gospodarczy Polski będzie - wraz $\mathrm{z}$ postępująca konwergencją systemowa - zmierzał w kierunku modelu unijnego. Oczywiście - tak jak to było do tej pory - będzie posiadał pewne specyficzne cechy wynikające z czynników społeczno-kulturowych. Do pełnej konwergencji systemowej nigdy nie dojdzie. Tego w UE nikt nie chce. Szukanie innej specyficznej polskiej drogi do kapitalizmu (gospodarki rynkowej) jest bardzo ryzykowne. Może się zakończyć niepowodzeniem. Historia Polski ostatnich 100 lat może nas wiele nauczyć.

\section{Literatura}

Balcerowicz L., 1993, Systemy gospodarcze. Elementy analizy porównawczej, „Monografie i Opracowania", nr 281.

Balcerowicz L., 2016, Trzeba sie bić z. PIS o Polske, Wydawnictwo Czerwone i Czarne, Warszawa.

Bałtowski M., 2009, Gospodarka socjalistyczna w Polsce, Wydawnictwo Naukowe PWN, Warszawa.

Bauman Z., 2018, Retrotopia. Jak rzadzi nami pržesz̨ość?, Wydawnictwo Naukowe PWN, Warszawa.

Democracy Index 2017, 2018, www.eiu.com/topic/democracy-index, [data wejścia: 20.06.2018].

Kołodko G.W., 1999, Ekonomia i polityka transformacji. Od szoku do terapii, Poltext, Warszawa.

Kołodko G.W., Koźmiński A.K., 2017, Nony pragmatyzm kontra nony nacjonalizm, Wydawnictwo Prószyński i S-ka, Warszawa.

Kowalik T., 2000, Wspótczesne systemy ekonomiczne. Powstanie, ewolucja, kryzys, Wydawnictwo Wyższej Szkoły Przedsiębiorczości i Zarządzania im. Leona Koźmińskiego, Warszawa.

Kozłowski S.G., 2004, Systemy ekonomiczne, Wydawnictwo UMCS, Lublin. 
Landau Z., Roszkowski W., 1995, Polityka gospodarcza II RP i PRL, Wydawnictwo Naukowe PWN, Warszawa.

Landau Z., Tomaszewski J., 1967, Gospodarka Polski miedžynojennej. Tom I-IV, Książka i Wiedza, Warszawa.

Mieszczankowski M., 1960, Struktura agrarna Polski miedsynojennej, PWN, Warszawa. Możemy lepiej!, 2018, rozmowa J. Żakowskiego z prof. Adamem Przeworskim, „Polityka”, nr 4.

Swadźba S., 2007, Integracja i globalizacja a system gospodarczy Polski. Konsekwencje dla Polski, Wydawnictwo Akademii Ekonomicznej w Katowicach, Katowice.

Swadźba S. (red.), 2009, Systemy gospodarcze. Zagadnienia teoretyczne, Wydawnictwo Akademii Ekonomicznej w Katowicach, Katowice.

Szpak J., 2003, Historia gospodarcza powszechna, PWE, Warszawa.

Wilkin J., 1995, Jaki kapitalizm? Jaka Polska?, Wydawnictwo Naukowe PWN, Warszawa. 